\title{
ERRATA TO VOLUMES 3 AND 4
}

\section{Volume 3}

1. On p. iv: The affiliations of Professor Mochtar Kusuma-Atmadja should read: Mochtar, Karuwin \& Komar, Jakarta; Professor of International Law, Pajajaran University, Bandung; member of the International Law Commission of the United Nations.

2. On p. 3: The first (editorial) footnote to "The International Court of Justice Retrospective and Prospects" referred to the presence of Judge Shigeru Oda at the Kampala session of the Asian-African Legal Consultative Committee "as an observer representing the International Court of Justice". Judge Oda in fact attended the Kampala session by invitation as an observer, but did not represent the International Court of Justice.

3. On p. 523: The acknowledgement of the subvention received from the Netherlands Ministry of Development Cooperation for the production and distribution of Volume One of the Yearbook, which was included in that Volume, was erroneously reproduced in Volume Three.

\section{Volume 4}

1. On p. 300: The reference to the "Announcement of 18 February 1993" should refer to: "Announcement of the Office of the Prime Minister concerning the Straight Baselines and Internal Waters of Thailand, No. 2, 2 February 1993".

In footnote 58 reference should also be made to: The Law of the Sea - Current Developments in State Practice, No. IV (UN Office of Legal Affairs, Division for Ocean Affairs and the Law of the Sea, 1995), p. 124.

The Editors and Publishers wish to apologize for the above errors, and for the omission in Volume 4 of the errata to Volume 3. 